\title{
WHITMAN IN THE (LATEST) SOVIET VIEW
}

\author{
JEROME LOVING
}

IN A CHARACTERISTIC DIATRIBE last year on ABC's "Nightline" (10 April 1985) the syndicated columnist William F. Buckley, Jr., dismissed as "twaddle" the proposition that the Soviets sought only "peaceful coexistence" with the United States. The particular target of Buckley's wit was the Soviet journalist Alexander Pallidin, and the subject of the news program was the value of a possible summit meeting between President Reagan and the newly installed Soviet leader Mikhail Gorbachev. Buckley, who when warned by anchor Ted Koppel against hurling "extraneous" insults had countered that his were "intrinsic," ridiculed the idea of a summit because, he said, "We are dealing with bandits that pay no attention to treaties." In response his Soviet opponent refused to trade insults with Buckley because, he said, one embarrassment to Koppel's program "was one too many." Like most commercial newscasts these days, it was more theater than substance, an outcome doubly assured in this case with the editor of the National Review pitted against the editor of Izvestia. What came through instead of "news" was the old story of the irreconcilable differences between capitalism and communism and their respective ways of viewing the world.

It is in this embattled context, seemingly remote from literature and its capacity to transcend the political, that we must locate our consideration of Whitman in the latest Soviet view. Earlier, under the skillful translations and interpretations of such post-Revolution scholars as Kornei Chukovsky and A. V. Lunacharsky, Soviet scholars were more tolerant of Whitman's individual eccentricities and did not try to fit him into Marxist categories. But more recent scholars, such as Maurice Mendelson in his Life and Work of Walt Whitman (translated into English in 1976), see Whitman more in accord with Soviet doctrine-at the very least as one unconsciously leaning towards collectivism in his poetry. "What I assume you shall assume," for example, celebrates the state before the individual-Marxism instead of its opposite Emersonianism, which as we all know teaches that when the poet or scholar goes "down into the secrets of his own mind he has descended into the secrets of all minds."1 Self-Reliance becomes then not even Self-Culture (defined in the Arnoldian rather than the Goethean sense) but a selfless celebration of collective thought.

It would be redundant to rehearse in particular more than a few of the questionable readings that abound in Mendelson's otherwise erudite book, one whose biographical and historical research are all the more remarkable considering the work was done wholly from inside the Soviet Union. My intention here is not to enter another "firing line" and hurl insults either "extraneous" or "intrinsic." Rather, I wish to take Mendelson's general thesis at 
face value - that is, when Whitman uttered "the word Democratic," he meant "the word En-Masse." 2 My premise is that in trying to iron out the political contradictions that earlier, less doctrinaire Soviet scholars were content to explore, Professor Mendelson may have alerted us to a collective strain in Whitman's poetry that is real and not merely the product of Soviet "twaddle."

Naturally, Mendelson, who was educated at Moscow State University during the Stalinist era, looks for a conscious reflection of socialist ideology in Leaves of Grass, noting that the only poem from 1850 to make it into the 1855 Leaves was "Europe (The 72d and 73d Years of These States)." Originally entitled "Resurgemus," the poem celebrates, among other European political activities, the French Revolution of 1848. Seeing the poem as "the foundation for Leaves of Grass," Mendelson also hears in it, he says, "the measured tread of the revolutionary masses." 3 Really, Mendelson states that one can almost hear that. And indeed most of his readings are finally dependent upon such a modifier. The same can be said for his thesis that Whitman in his early development as a poet was preoccupied with social problems. As a journalist in the late 1840 s Whitman covered their entire range in numerous editorials, but such facts become the fiction of Leaves of Grass, where the song of the self is weaved from the multitude. Even the problem of slavery, which Mendelson claims gradually pushed Whitman towards socialism, was blunted by the poet's Transcendentalist optimism. In fact, during the Civil War he shared with Lincoln the initial willingness to abide slavery if its immediate abolition meant the breakup of the Union.

This is not to suggest that Whitman would have preempted his best imitator Carl Sandburg and written a poem entitled The People, No, but merely to observe that politically he was no romantic. He may have left to Providence the problem of slavery's expansion during the Mexican War, but by the 1850s he had grown cynical of the political process and abandoned politics for poetry. Hence the largely apolitical character of Leaves of Grass. Even Mendelson has to admit that its greatest poem, "Song of Myself," does not "deal specifically with slavery or the struggle against slavery." 4 He does argue, however, that despite the fact that the self stands at the center of the poem, "Song of Myself" also contains "many, many heroes. The apparent contradiction between the lyrical essence of 'Song of Myself' and the presence of a great many different characters," Mendelson contends, "is resolved in an unusual manner - the poet constantly reincarnates himself into other people; the image of the poet contains many different images."5

It is here, I think, that Mendelson makes his most telling point about Whitman. Rather than rely upon a psychological/romantic reading (really the only way out for the Jeffersonian democrat of the twentieth century), this Soviet scholar (an American expatriate, incidentally, who migrated to the U.S.S.R. in the 1930s) finds in the protagonist's self-deification a demographic of the spirit, if you will, which deposits the identity of the self with the multitude instead of with the Transcendentalist "Me" or Oversoul. In 
such a schema, the "Not-Me" of Emersonianism becomes everything and God nothing. Atheism, as we all know, is the national "religion" of the Soviet Union. One has only to walk the boulevards of Leningrad or Moscow to learn that Lenin has become its Christ. His ubiquitous icon symbolizes neither a virgin birth nor a rebirth but simply the "measured tread" of the One-in-the-Many. Mendelson's Whitman projects himself into the mass, becoming at once the hounded slave, the freed black, the omnibus driver-in sum, the "Divine Average" who are "divine" precisely because of their great number and "average" because they represent the common denominator of the self.

In another essay I have stated that Whitman advanced Transcendentalism by contradicting it, ${ }^{6}$ but Mendelson's reading of Whitman appears to take the Body too far. For here the Body-or the People-is not equal but superior to the Soul, or the thing that supposedly peoples. We might turn to Matthew Arnold for help instead of Emerson or even Whitman, for when the American poets make the transition (in their later work) from self to society, or Culture, they are not any longer doing the work for which most of us now honor them. Arnold, on the other hand, begins his career more or less in protest against the heady romanticism of England. The Romantics, he argues in Essays in Criticism, First Series (1864), had "plenty of energy, plenty of creative force," but they simply did not know enough about their world. ${ }^{7}$ They practiced Self-Reliance instead of-what I am admittedly using as an honorific in this essay-Self-Culture. As he makes clear in Culture and Anarchy (1869), both Self-Reliance and Self-Culture allow the free play of the imagination-or what Arnold terms "curiosity"-but the first begins with curiosity, while the second has "its origin in the love of perfection." SelfCulture is not merely the endeavor to celebrate the self on its own terms but to celebrate that self's epiphany as the catalyst towards the moral and social improvement of the whole. This "idea of perfection as a general expansion of the human family," Arnold notes, "is at variance with our strong individualism, our hatred of all limits to the unrestricted swing of the individual's personality, our maxim of 'every man for himself.'"8

One can readily understand Arnold's disapproval of Whitman's "unrestricted swing" in "Song of Myself." Upon receipt of a complimentary copy of The Good Gray Poet (1866), he agreed with its author, William Douglas O'Connor, that Whitman's act of free speech in Leaves of Grass should not have cost him his government job. But as to the poetic act itself, he told O'Connor: "you will think that it savours of our decrepit old Europe when I add that while you think it his highest merit that he is so unlike anyone else, to me this seems his demerit. ... a great original literature America will never get in this way, and her intellect must inevitably consent to come, in a considerable measure, into the European movement."9 Arnold here is alluding not only to the tradition of world literature Whitman pretends to ignore. With both the English and American romantic movements safely behind him 
and the industrialization of England completed, he was probably also referring to the poet's social responsibility and that of literature in general to fill the gap left by the dissipation of organized religion in the nineteenth century. A year later in Arnold's own country, Karl Marx published the first volume of Das Kapital, and the "frontier" of the self by itself irrevocably vanished. Despite Thomas Carlyle's insistence upon the dangers of democracy in "Shooting Niagara: and After?" 10 - merely reiterated arguments from the days of Heroes and Hero-Worship (1841)-the era of the romantic, the natural or auto-aristocrat in literature, had passed. What remained was the "quiet work" of the social self.

This is not to suggest that Arnold was simply making the classic protest against romanticism, but that he knew poetry had to do more in an age of pluralism and social responsibility. In an earlier time, the romantic poet's introspective celebration was at least not counter-productive in the Shelleyean sense that poetry also encourages the improvement of the social self. But the Victorian period of transition and "spiritual discomfort" required not only an aesthetic appreciation of nature but a celebration of "the idea and laws of the inward world of man's moral and spiritual nature."11 Whitman's stoicism, therefore, his self-reliant individualism, was already out of date in 1866 when Arnold wrote to O'Connor. It was not enough for an age begun in America with the Emancipation Proclamation and in England with the Parliamentary Reform Bill of 1867. The first freed the slaves in the New World; the second enfranchised the urban working class of the Old.

Whitman himself probably realized the problem in 1868 when he called for a self-culture (he called it "Personalism") predicated on the practical life of working class America. ${ }^{12}$ In the poetry that followed, such as "Passage to India," the hero is not exactly the solitary singer but the world which is finally united both physically and spiritually. One can easily appreciate the pressures this so-called "Poet of Democracy" endured during America's socalled period of Reconstruction. Democratic Vistas (1871) hints of the strain and drain upon his optimism. But of course Whitman's later work is not the primary focus of Mendelson's claim. And rather than dismiss the critic as a hopeful revisionist, we must return to the problem of those "many, many heroes" he finds in "Song of Myself."

Whitman had always sought to be the poet of the people-the "roughs" as he called them. In recalling to Horace Traubel one of his encounters with Emerson, he bragged that the man from Concord had envied the Brooklynite's native familiarity with the common man. ${ }^{13}$ These are the folks who people "Song of Myself," but the general view of their role there is that they are merely projections of the Transcendentalist or "imperial" self, not vice versa. That is to say, the poem celebrates the individual as individual and not as a member of a collective in which-echoing Marx-equality means that everyone works according to his faculties and receives according to his needs. But is this so in Leaves of Grass? The bedraggled prostitute in "Song of 
Myself"-one of Whitman's misérables -is to be treated as well as the mother she might become someday. Later, in "To a Common Prostitute," the poet salutes her "with a significant look" that appoints the time when she will contribute as much to society as the "President holding a cabinet council." Equality is also extended to the prostitute's "fancy-man" or pimp as well as to the dope fiend, the prisoner, the "cotton-field drudge," the "cleaner of privies," and the "venerealee." Whitman freely admits: "Of these one and all I weave the song of myself."

Perhaps the key to Whitman's "socialism" is found in the verb he chooses in the final sentence of his 1855 Preface. He says that the proof of a poet is that his country absorbs him as much as he absorbs them. Rather than becoming the selves or tendencies that form the solitary singer's psychomachia, they are real people - the mass which "absorbs" each and every part or individual. Whereas the Emersonian poet or self-reliant man is the Whole that is greater than the sum of its parts or society, Mendelson's poet is always the part of the Whole. In this society everyone contributes or will contribute according to his faculties and receive according to his needs:

\footnotetext{
The butcher-boy puts off his killing clothes, or sharpens his knife at the stall in the market,

Blacksmiths with grimed and hairy chests environ the anvil,

The negro holds firmly the reins of his four horses, the block swags underneath on its tied-over chain. . . .
}

"By God!" the poet exclaims, "I will accept nothing which all cannot have their counterpart of on the same terms." Through him, the poet tells us, we can hear "many long dumb voices." We hear the "pass-word primeval" which is equality. "Song of Myself" is really then the song of myself, himself, and herself. What the poet "assumes," we all have a right to assume. We can assume that we are a part of the Whole, and no more.

In Mendelson's scenario, the hero of "Song of Myself" is never alone or out in the woods as Emerson's "transparent eye-ball" but on the "open road" as our parent who shows us the way, pointing-as it were-in the fashion of Lenin. If as in Section 5 he points to his present instead of our future, it is because he is contradicting himself again. As he tells us, he contains "multitudes"-not the multitude. I suggested at the outset of this paper that I can find only a collectivist strain in Whitman's poetry, not the Marxist ideology Mendelson insists upon. Yet the tendency may be more significant than the tenet. For it anticipates the inevitable shift from Self-Reliance to Self-Culture, if not to communism. After Whitman, no serious poet could celebrate himself with such abandon. No wonder Emily Dickinson found him "disgraceful." If one was to carry on such egotism, to select his own society, he ought to have done so behind closed doors - as she did. Otherwise, 
the artist paid a high price for his Self-Reliance. Few ran the risk in the twentieth century. James Joyce tried it and got himself exiled from his country. Ezra Pound tried it and got jailed in his country.

In "Tradition and Individual Talent" T. S. Eliot largely disposes of the romantics by declaring that poetry "involves, in the first place, the historical sense, which we may call nearly indispensable to any one who would continue to be a poet beyond his twenty-fifth year." 14 He means that no great poet writes in isolation but must reflect in his work the tradition of great poetry before him. He must absorb the past into the present. Arnold said as much about Whitman (who is obviously the secret subject of Eliot's essay) in his letter to O'Connor. Yet if my reading is correct, Arnold also hinted that great poetry requires not only a sense of the past but one of the future as well: the poet has to strive "to leave the world better and happier than [he] found it."15 Arnold's answer is Culture, whereas Eliot's is ultimately a religious aesthetic that relies upon the myth of the One Mind in an eternal present. But neither functions in the self-reliant isolation that produced the first edition of Leaves of Grass. Somewhere between Arnold and Eliot, Whitman with the multitude before him and his back to the past gets lost in our literary history and re-emerges - if we are to believe Mendelson-as a Marxist. The view is extreme, but its mere assertion reminds us that today Whitman cannot be read as confidently as he once could. As his present readers, we are somehow held "hostage" by the growing suspicion that the poet's "divine average" has already moved on to a newer world. In other words, Whitman celebrated Self-Reliance in the New World, but that world is now "old" in the sense that America no longer supports the ideology of an emerging nation. In spite of our social ills (and there are many), we no longer require a poet of democracy but rather one of demography. The Soviets claim they do because they have (as they are fond of reminding American Fulbrighters) only recently emerged from the cocoon of Czarist Russia. Or at least Marxist theory, if not Soviet practice, calls for such a poet. They need to hear their "America" singing, while all we now hear is the silent "Song of Myself."

\section{Texas $A$ E $M$ University}

\section{NOTES}

1 "The American Scholar" in Selections from Ralph Waldo Emerson (Boston: Houghton Mifflin Company, 1957), p. 74.

2 “One's-Self I Sing," in Sculley Bradley and Harold Blodgett, eds., Leaves of Grass, Comprehensive Reader's Edition (New York: New York University Press, 1965), p. 1.

3 Life and Work of Walt Whitman: A Soviet View (Moscow: Progress Publishers, 1975), p. 84 .

4 Life and Work, p. 126.

5 Life and Work, p. 126. 
6 "Walt Whitman" in The Columbia History of American Literature, ed. Emory Elliott (New York: Columbia University Press, 1987), forthcoming.

7 Matthew Arnold: Lectures and Essays in Criticism, ed. R. H. Super (Ann Arbor: University of Michigan Press, 1962), p. 262.

8 Matthew Arnold: Culture and Anarchy, ed. R. H. Super (Ann Arbor: University of Michigan Press, 1965), p. 95.

9 Quoted in Bliss Perry, Walt Whitman: His Life and Work (Boston: Houghton Mifflin Company, 1906), pp. 177-179; see also Jerome Loving, Walt Whitman's Champion: William Douglas O'Connor (College Station: Texas A \& M University Press, 1978), pp. 71-72, 203n.

10 New York Tribune, 16 August 1867.

11 Arnold, Culture, p. 95.

12 “Personalism," Galaxy, 5 May 1968.

13 Horace Traubel, With Walt Whitman in Camden (Boston: Small, Maynard, 1906), 1:61.

14 The Sacred Wood: Essays on Poetry and Criticism (London: Methuen \& Co., 1920), p. 49.

15 Culture and Anarchy, p. 91 